\title{
ALOHA ANOHA! - zpráva z návštěvy připravované dětské expozice Židovského muzea v Berlíně \\ Magdalena Bližňáková
}

\section{ALOHA ANOHA! - Report from a Visit to the Upcoming Children's Exhibition of the Jewish Museum in Berlin}

Inspirativnost mezinárodní muzejní spolupráce je nesporná. O tom se na konci února 2020 přesvědčilo Oddělení vzdělávání a kulturních aktivit Národního muzea, které bylo dr. Ane Kleine-Engel, ředitelkou dětského muzea ANOHA při Židovském muzeu v Berlíně, pozváno na návštěvu. Cílem zahraniční cesty bylo osobní setkání s berlínskými kolegy, výměna zkušeností a seznámení se s novou expozicí Židovského muzea věnované dětem, jejíž otevření realizátoři plánovali na květen tohoto roku.

Dětské muzeum ANOHA se nachází v Blumenthalově akademii na berlínské Lindenstrasse naproti Židovskému muzeu. Součástí budovy je vedle prostoru nové expozice též edukační zázemí pro děti, školáky i učitele, auditorium a tematicky zaměřená knihovna s archivem. Právě efektivní zvuková izolace nově připravované interaktivní expozice a posluchárny s knihovnou, sídlící v budově od roku 2013, byla jednou $\mathrm{z}$ největších výzev tvưrčího týmu.

Základní myšlenka „dětského světa Židovského muzea" spočívá ve vykreslení rozmanitosti a propojenosti života na Zemi na pozadí starozákonního příběhu o arše Noemově. V první, úvodní části expozice se nejmenší návštěvníci seznámí s biblickým příběhem audiovizuální formou. Následuje zvuková evokace deště a velké vody, která v První knize Mojžíšově smete hříšné lidstvo $\mathrm{z}$ povrchu zemského. Za účelem navození atmosféry blížící se povodně se využívá zvukového doprovodu deště a čtyř kruhových objektů oslovujících další lidské smysly.

V navazující části expozice mají děti možnost vyrobit si z rozličných materiálů svou lod'ku, vlastní Noemovu archu, kterou následně pustí na vodní překážkovou dráhu. Sledují pak, zda jejich archa zdolá nástrahy a zdárně dorazí do cíle. Rozhodnutí o tom, že se v muzeu bude nalézat větší množství vody, se kterým návštěvníci přijdou do styku, komentovala dr. Kleine-Engel jako odvážné.

Hlavní prostora nové expozice je členěna velkou dřevěnou archou, navrženou americkou architektonickou firmou Olson Kundig, umístěnou ve středu sálu, s několika vstupy různé velikosti. Ty jsou tam vytvořeny proto, aby se dovnitř potenciálně vešly všechny druhy zvířat, která jsou rozmístěna po celé expozici a tvoří její obsahovou dominantu.

Tvůrci předpokládají, že děti budou plastiky zvírat rozpoznávat a prozkoumávat. Počítá se, že samy nebo za přispění doprovodu dojdou k zjištění, že některým tvorům mohou do archy pomoct; jedná se například o ledního medvěda, který je zavěšen na posuvném popruhu tak, aby jej návštěvníci mohli manuálně přetáhnout dovnitř záchranné lodě. Na podobném principu funguje pomoc orangutanovi, kterému navíc v klíně sedí několik menších zvířat. Proč? Opice může díky své velikosti a obratnosti zachránit menší zvírata, která by to sama včas do archy nemusela stihnout. Muzeum tedy klade zvýšený důraz jednak na haptickou linku celé expozice, jednak podněcuje děti k přemýšlení, empatii a soudržnosti. Nenásilnou cestou je nabádá k solidaritě se zvíraty i s přírodou; všechna přítomná zvíŕata jsou totiž stejně jako archa a veškeré vybavení interiéru expozice vytvořena ze zbytkových materiálů a starších použitých předmětů nejrůznější povahy.
Mgr. Magdalena Bližňáková Centrum pro prezentaci kulturního dědictví Národní muzeum magdalena.bliznakova@nm.cz 


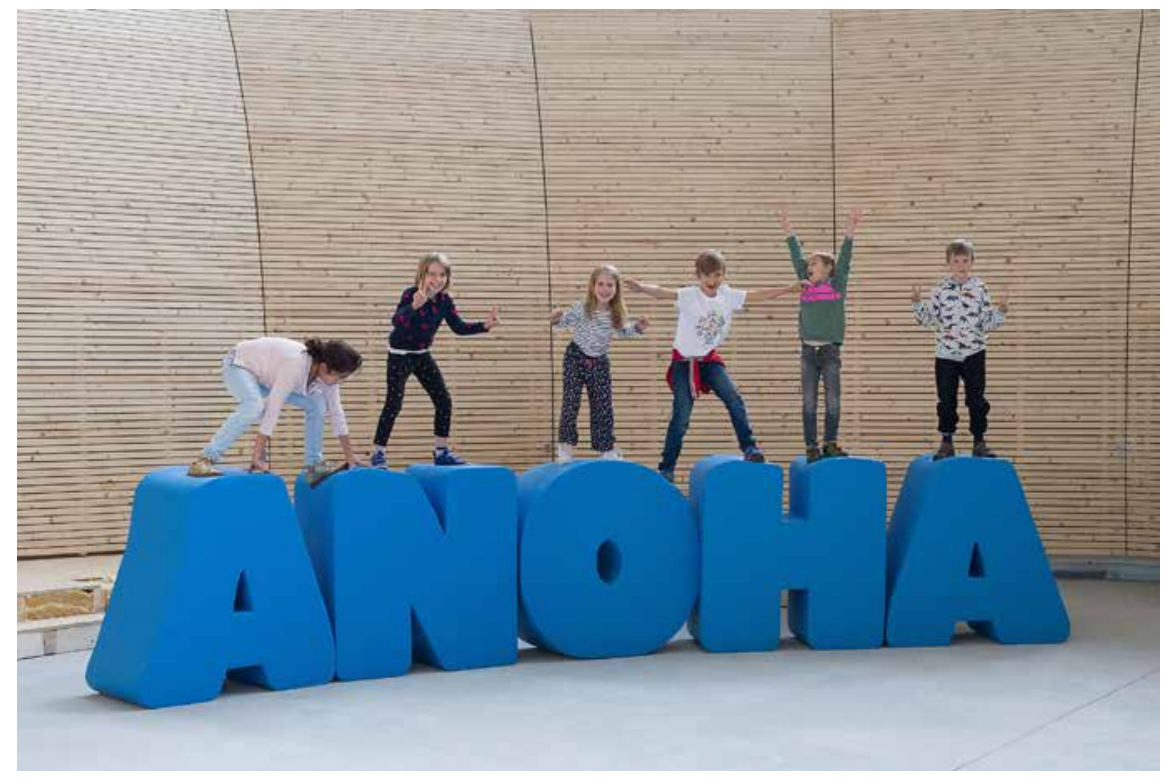

Děti na vstupním nápisu $v$ expozici ANOHA

(C) Židovské muzeum Berlín; foto: Sibylle Baier

1 Od dr. Kleine-Engel jsme se dozvěděly o snahách umístit do expozice (konkrétně do nitra archy) svitek Tóry, tedy alespoň jednu muzeálii.
Dětští návštěvníci mohou prozkoumat na sto padesát plastik rozličných tvorů od třiceti současných německých umělců a za prítomnosti doprovodu si vyzkoušet některé zviŕrecí dovednosti při zdolávání opičích drah či šplhání ve výškách. Nakouknout lze do liščí nory, zakusit na vlastní kůži smyslový aparát netopýrů, seznámit se s ekologickým koloběhem potravy a hnojiva zemědělského dobytka, dolepit mamutovi část srsti nebo si jen odpočinout na nadživotně velkém, koberci vystlaném lenochodovi.

Je zřejmé, že nové berlínské dětské muzeum je koncipováno jako zážitkový mikrokosmos umně propojený se starozákonním př́během a aktualizovaný o současnou ekologickou otázku. Tvůrci kladli dưraz na samostatné bádání dětí bez významnějšího vysvětlování z jejich strany - od toho tu nejsou popisky ani průvodci, ale rodinný doprovod dětského návštěvníka nezbytný ke vstupu do muzea (platí zde princip reciprocity, kdy ani dospělému není umožněn vstup do expozice bez dítěte). Muzeum tak vytvář́i prostředí s potenciálem mezigeneračního učení.

Kromě individuálního poznávání se v muzeu počítá i se skupinovými workshopy, animátorskými programy, s narozeninovými oslavami, hravým zázemím pro nejmenší děti a edukačním prostorem uvnitř části archy pojednaném jako komornější posluchárna. Zajímavým přesahem, kdy se obsah a cíle expozice zprostredkují mimo stěny muzea, je mobilní vzdělávací program, který připravuje outreach manager muzea Jonas Nondorf.
Tvưrčí tým dětského muzea ANOHA přistoupil nekonvenčně $\mathrm{k}$ obsahu i formě expozice. Ačkoli se jedná o prostor náležející Židovskému muzeu, a tedy muzejní prostor, v nové expozici kromě popisků nenalezneme ani žádné exponáty ${ }^{1}$. To nás přivádí k otázce, zda se nový berlínský projekt dá považovat za muzeum, které je dle přetrvávajícího úzu vytvářeno reprezentativními autentickými předměty (muzeáliemi). Do klasické definice muzea se ANOHA nevměstná, ale to její tvůrci ani neměli v plánu. Naopak se chtěli vymanit ze zažité představy o muzeu, kde je zakázáno se čehokoli dotknout, a umožnit návštěvníkům přímou interakci s objekty. S odkazem na Michaela Spocka, průkopnického ředitele Bostonského dětského muzea v letech 1962-1985, se realizační tým berlínského muzea přiklonil $\mathrm{k}$ názoru, že to, čím se dětské muzeum odlišuje od ostatních muzeí, je dưraz kladený $\mathrm{v}$ první řadě na návštěvníka a až $\mathrm{v}$ druhé na předměty. $S$ tímto př́stupem souvisí tvưrčí zapojení tzv. dětské rady, školáků od osmi do jedenácti let, kteří se podíleli na př́pravě expozice tím, že realizační proces pravidelně a průběžně připomínkovali. Slovo dostali i v rozhovoru pro číslo JMB Journalu s podtématem Budoucnost, kde se konkrétně Laurin a Anton vyjádřili k otázce, čím se dětské muzeum liší od klasických muzeí. Děti kvitovaly absenci textů i audio nahrávek, díky čemuž dostanou více prostoru pro samotné vyzkoušení předmětů a hru s nimi. Ocenily také tvưrčí možnosti, které muzeum nabízí. Nejen že si budou moci vyrobit tematické výtvory (při zkušebních workshopech dětští poradci např́iklad tvořili z recyklovaných materiálů své oblíbené zvíře nebo ve skupině vymýšleli a realizovali imaginárního tvora), ale svůj výtvor budou moci v muzeu zanechat pro ostatní - vložit jej do vitríny nebo nahrát k poslechu či ke zhlédnutí. Děti samy se tak stanou spolutvưrci muzea.

Tvůrčí tým si svých dětských poradců velmi cení. Přišli s podnětnými nápady, pojmenovali stěžejní témata celého projektu a podle programové ředitelky Źidovského muzea (2017-2019) Léontine 


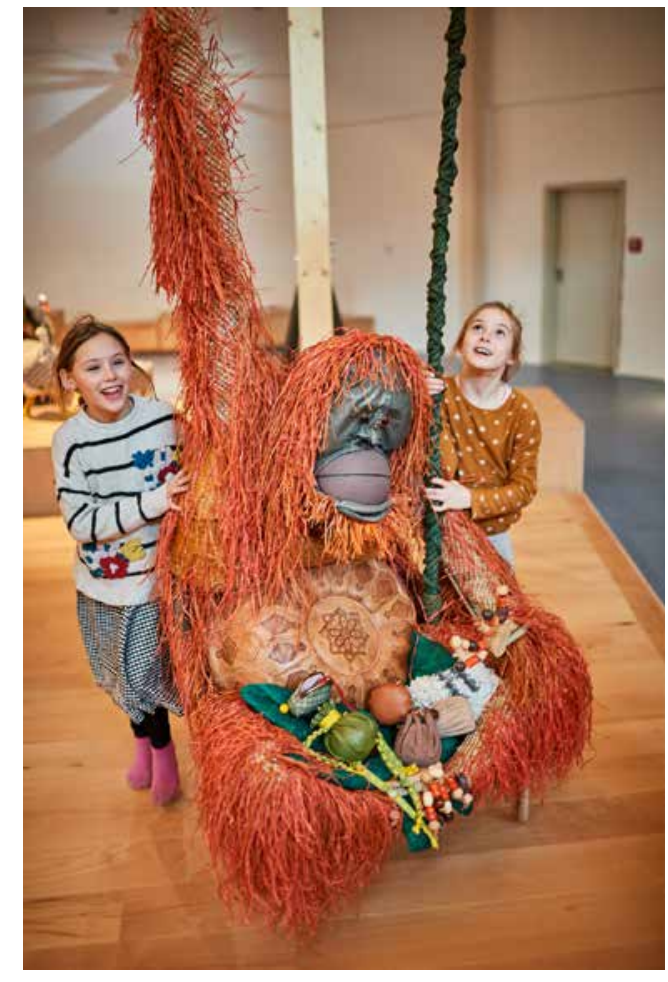

U vstupu děti společně s orangutanem pomáhají malým zvířatům do Archy. (C) Židovské muzeum Berlín, foto: Yves Sucksdorff

Meijen-van-Mensch připomněli dospělým, jak důležité je naslouchat přáním a potřebám mladých lidí. Ti si ze zkušenosti členů realizačního týmu uvědomují klimatické změny, s nimi se pojící vymírání zviŕrecích druhů a sucho střídané povodněmi. Cílem muzea je $\mathrm{v}$ dětských návštěvnících utvářet a podporovat vědomí přináležení každého tvora na Zemi. A to bez ohledu na jeho intelekt, velikost, sílu, barvu či odlišný jazyk. Téma velké potopy a záchranné archy, objevující se v základech židovství, křestanství i islámu, rezonuje také ve 21. století; v multikulturním Berlíně pak o to silněji. Návštěva novátorské expozice ANOHA byla velmi inspirativní a podnětná, obzvláště v době, kdy se oddělení vzdělávání a kulturních aktivit podílí na vzniku dětského muzea v Nové budově Národního muzea. Tímto bych ráda poděkovala naší průvodkyni, ředitelce dr. Kleine-Engel, a Jonasi Nondorfovi, který nás seznámil s plánovaným outreach programem, za vřelé přijetí a ochotu, s nimiž nám umožnili nahlédnout "pod pokličku" nově vznikajícího muzejního projektu pro děti.

\section{Použité zdroje}

Blogerim - from the corridors of the Jewish Museum Berlin: Why the Jewish Museum Berlin has every reason to finally open a children's museum in 2019. [online]. [cit. 12. 5. 2018] Dostupné z: https://www.jmberlin.de/ blog-en/2018/05/why-the-jewish-museum-berlin-has-every-reason-to-finally-open-a-childrens-museum-in-2019/.

Jewish Museum Berlin: JMB Journal Nr. 17. [online]. [cit. 11. 12. 2017] Dostupné z: https://issuu.com/jmb_journal/docs/ jmb_journal_2017_2_original_.

ANOHA. Die Kinderwelt des Jüdischen Museums Berlin. [online]. [cit. 11. 12. 2017] Dostupné z: https://www.jmberlin.de/ANOHA. 